the hon. treasurers of the Ramsay Memorial Fund at University College, London, W.C.I.

H. H. Asquith.

D. Lloyd George.

GAINFORD.

RAYLEIGH.

REAY.

Rosebery.

H. A. L. Fisher.

J. J. THOMSON.

Hugh BELl.

Glenconner.

June 16.

$$
\text { President. }
$$

Vice-Presidents.

$\{$ Chairman of the Executive Committee.

Treasurer.

THE CATERPILLAR ATTACK ON FRUIT TREES.

$A$ GOOD deal has been heard recently about A the caterpillar plague on fruit trees. There has undoubtedly been an abnormal attack in many parts of the country, and much damage has been done. In some parts of Kent, Sussex, Herefordshire, and Worcestershire orchards have been denuded of their foliage, and many more partially damaged. In many instances not only has this year's promising crop gone, but the trees have had a serious setback for next season. Apples and cherries have suffered most, but in a few districts plums have been badly invaded; currants also have suffered. In some districts visited much of the fruit was only slightly affected; some orchards well cared for, not at all; whilst others were as bare as in midwinter, and a fresh set of leaves was already appearing.

Most of the harm has been done by the Winter Moth (Cheimatobia brumata). In company with it has been a fair sprinkling of the Mottled Umber (Hybernia defoliaria) larvæ. Another "Looper" larva has done much harm in parts of Herefordshire, the Pale Brindle Beauty (Phigalia pilosaria), and also in Kent and at one locality in Sussex; it is usually worst in plantations near oakwoods. Comparatively few March Moth (Anisopteryx aescularia) have occurred. All those mentioned have either apterous or nearly apterous females, and are incapable of flight. A few are, however, carried by the males in copula. From several localities in Kent and Sussex numbers of Clouded Drab Moth (Taeniocampa instabilis) have been received; this insect appears to be becoming more harmful to fruit in the south of England.

The main damage done has clearly been due to the insects mentioned, by far the greater part by the Winter Moth, the Pale Brindle Beauty having been very harmful in a few localities only. These caterpillars have now done most of their work, but the fruit-grower is still being harassed to some extent by the Lackey Moth (Clissiocampa neustria) and the Little Ermine (Hyponomeuta padella). How far these attacks will develop it is impossible to say.

The amount of loss has been due very largely to the serious lack of labour. Many plantations have been improperly cultivated or from lack of labour, not cultivated at all. It has too often been quite impossible to spray the trees, and even

last year there were not sufficient men on many farms effectually to grease-band them. For Winter Moth and its allies two methods of treatment meet with complete success, if properly carried out, which can only be with the necessary supply of skilled labour. The first is greasebanding; the second, spraying with arsenate of lead, where the former cannot be done, as on bush trees or where such pests as the Clouded Drab Moth occur. If grease-banding on standards and half-standards is to be of any use, the bands must remain sticky from October to April, and the bands must be complete, not, as the writer has seen this year, with many breaks in them. If arsenate of lead spraying is done, then, it must be carried out at the proper time and thoroughly. Many growers have sprayed when they found the blossom trusses going and the leaves fast disappearing. This is too late, for the damage is done, the caterpillar working most rapidly towards the close of its life. Apples should be sprayed as soon as the buds are well open, and may have to be sprayed again when the blossom trusses begin to expand. One good spraying as soon as the young "Looper" larvæ are seen will save the crop, whilst to spray when all the damage is done is waste of time and money.

Most of the loss this season to apples and other fruit could, and doubtless would, have been saved had proper provision been made for the necessary skilled labour.

One other point is worth mentioning, namely, that during the winter in many districts there was a great mortality amongst sparrows. The sparrow, especially when nesting, devours Winter Moth larvæ and undoubtedly helps to keep them in check, which, however, will not make up for its many evil habits.

Fred. V. Theobald.

\section{PROF. T. MCKENNY HUGHES, F.R.S.}

\section{THOMAS McKENNY HUGHES, Wood-} wardian professor of geology in the University of Cambridge, died at Cambridge on June 9, in his eighty-fifth year.

Hughes was born at Aberystwyth, and was the son of the Rev. Joshua Hughes (afterwards Bishop of St. Asaph), and grandson of Sir Thomas McKenny, Bart., who took a prominent part in promoting Catholic emancipation in Ireland. His brother is Bishop of Llandaff. On leaving school, he entered Trinity College, Cambridge, where he graduated in 1857 , proceeding to the M.A. degree ten years later. When an undergraduate he attended the geological lectures of his predecessor in the Woodwardian chair, Prof. Sedgwick. In I86o he was appointed secretary to the British Consul at Rome, and during part of that and the following year was left in charge as Acting Consul; but before the year r 86 I closed he definitely gave up diplomacy for geology, and joined H.M. Geological Survey. $\mathrm{He}$ was a member of the Survey until 1873, when he was elected to the Woodwardian professorship. From thiat date until his death his time and energy were devoted to the cause of the Cambridge

No. 2486 , voL. 99] 
School of Geology, with a success which is fully proved by the high position which that school now occupies.

Hughes's life-work may be conveniently regarded under two heads: his original work in geology and archæology, and his labours in connection with the Cambridge School. The greater part of his geological researches was carried out during his period of service on the Geological Survey and the earlier part of that of his occupancy of the Woodwardian chair. The duties of his professorship became heavier as time went on, and the output of geological papers naturally diminished, though it by no means ceased. During this time he found a pleasant relaxation from official work in archæological study, and enriched many archæologićal journals with contributions of considerable interest and value, many of which dealt with the antiquities of the Cambridge district.

His most important geological writings were concerned with some of the earliest and the latest deposits. He took a prominent part in the establishment of the pre-Cambrian age of certain rocks of North and South Wales, and wrote much of value concerning the Lower Palæozoic rocks of the Principality and of the borders of Lakeland. He was greatly attracted by the many vexed questions connected with the Glacial and post-Glacial deposits, especially those bearing upon the problem of the antiquity of man: here, also, he added much to our knowledge.

The value of Hughes's work was gracefully recognised by Sir Archibald Geikie when, as president of the Geological Society, he presented Hughes with the Lyell medal in I891 :- "You have not confined yourself . . . to the rocks of any one system or period, but have ranged freely from Archæan gneiss to raised beach, hovering for a moment here and resting a little there, generally critical, almost always suggestive, and with that happy faculty of enthusiasm which, reacting on younger minds, "allures to older worlds, and leads the way.',

Turning now to Hughes's work in connection with the Cambridge School of Geology, one was struck by his many qualities making for success. In addition to his scientific attainments, he possessed an acute instinct for judging character, unbounded energy, and an exceptional degree of enthusiasm, which he retained to the end, Not the least of his qualities were those social ones which, causing him to be a favourite among all ranks, were peculiarly valuable when dealing with those with whom he was brought into contact in his official capacity. He exercised a wise control over his department. Using much judgment in the selection of his subordinates, he ever afterwards allowed them a freedom of action which not only ensured a smoothness in the working of the machinery, but also greatly increased its efficiency. Much of the teaching was left to the lecturers and demonstrators, but his own courses were very attractive and highly appreciated. His qualities as a teacher stood out most prominently when conducting field excursions, whether around NO. 2486, VOL. 99]
Cambridge or in other parts of the country. Few gatherings were more delightful than those at his long excursions, and the amount of knowledge acquired by his pupils was great, for Hughes was at his very best on these occasions.

Hughes was very successful in inducing people to take up the study of geology, and was responsible for the addition of many to the ranks of that body which is now becoming all too limited - that of the amateur geologists. To all students alike he was accessible and ever ready with help in the museum and at his home. Here he was greatly aided by his accomplished wife, who died last year. She was the daughter of the Rev. G. F. Weston, Hon. Canon of Carlisle, and was an able geologist and naturalist.

Owing partly to Hughes's own exertions, partly to his persuasive manner, he left the collections in the Sedgwick Museum, already valuable at the time of his election to the professorship, much enriched by his labours. Especially noteworthy is the collection of building stones, marbles, etc., brought together by Mr. John Watson, M.A., through the professor's influence, for he was fully aware of the importance which economic geology must assume in university study. Not only did he add largely to the collections, but, after many delays, he had the satisfaction of seeing them housed in the magnificent Sedgwick Museum, which, largely owing to his unwearied efforts, was completed and finally opened by King Edward VII. in I904. Another task which partly fell to him was the writing of the life of his predecessor in office. This was finished in $r 89 r$, when "The Life and Letters of the Reverend Adam Sedgwick," by John Willis Clark and Thomas McKenny Hughes, appeared.

For want of space, full notice cannot be taken of his many activities unconnected or only indirectly connected with geology, but mention must be made of his interest in agriculture. He took an active part in the proceedings of the Cambridge and Isle of Ely Chamber of Agriculture, of which he was a past-president.

Some of the positions which Hughes occupied and the honours he received have already been mentioned. In addition, he was a professorial fellow of Clare College, F.R.S., and honorary member of many British and foreign learned societies. He was also a Chevalier of the order SS. Maurice et Lazarus (Italy).

It is interesting to note that Hughes and his predecessor occupied the Woodwardian chair for ninety-nine years.

He leaves three sons, all of whom are serving in the Army.

J. E. MARR.

\section{NOTES.}

A MEMORIAL tablet, including a medallion portrait of the late Sir William Ramsay, K.C.B., F.R.S., is to be erected in the University of Glasgow, of which he was a graduate and teacher. The University Court has arranged that the memorial, which is designed by Sir John J. Burnet, shall be placed in a conspicuous position at the entrance to the Bute Hall. 